\title{
Diatom Epipelik sebagai Bioindikator Pencemaran di Estuari Suwung
}

\author{
Yesie Rahayu Ananingtyas ${ }^{a *}$, I Gede Hendrawan a, Yulianto Suteja ${ }^{a}$ \\ a Program Studi Ilmu Kelautan, Fakultas Kelautan dan Perikanan, Universitas Udayana, Kampus UNUD Bukit Jimbaran, Bali 80361, Indonesia \\ * Penulis koresponden. Tel.: +62-133-873-0165 \\ Alamat e-mail: yesierahayu18@gmail.com
}

Diterima (received) 19 Juli 2017; disetujui (accepted) 6 September 2017; tersedia secara online (available online) 8 September

\begin{abstract}
Epiphelic diatoms are the living diatoms adhere to the bottom substrate of the waters. Epiphelic diatoms ware used as bioindicators because sensivity of enviromental change, widely distributed, and ware not affected by currents. Epiphelic diatom research as a bioindicator of pollution in the Suwung estuary was conducted in December 2016 and January 2017. The sampling of epiphelic diatom using the method of "Lens tissue trapping method". The results of research in December 2016 found 34 species of epiphelic diatoms, while in January 2017 found 24 species of epiphelic diatom. Species that are often found in this study are Pleurosigma clavei, Rhabdonema arcuatum, Synedra gailloni and Gomphonema angustatum. The highst of epipelic diatom abundance in estuari suwung in January 2017 was 8.82 $\mathrm{Ind} / \mathbf{m}^{2}$ and the lowest epiphelic diatom abundance of $0.41 \mathrm{Ind} / \mathbf{m}^{2}$. The assessment of contamination using epiphelic diatom using two methods such as diversity index and saprobik index. The pollution assessment based on the diversity index shows that in December 2016 it was varied, not contaminated, mildly polluted, moderately polluted while the saprobic index-based valuation was varied ie clean, moderately polluted and heavily polluted. Assessment of pollution with saprobik index is used to know the contamination of organic matter. Diversity index in January 2017 and the saprobic index had the same pattern that almost of station research in Suwung estuary research stations were moderately polluted and there was an increase in pollution.
\end{abstract}

Keywords: epipelic diatoms; diversity index; saprobik index

\begin{abstract}
Abstrak
Diatom epipelik adalah diatom yang hidup menempel pada sedimen. Diatom epipelik digunakan sebagai bioindikator karena sangat sensitif terhadap perubahan lingkungan, persebarannya luas, dan tidak terpengaruh oleh arus. Penelitian diatom epipelik sebagai bioindikator pencemaran di estuari Suwung dilakukan pada bulan Desember 2016 dan Januari 2017. Pengambilan sampel diatom epipelik menggunakan metode "Lens tissue trapping technique". Hasil penelitian pada bulan Desember 2016 ditemukan 34 spesies diatom epipelik, sedangkan pada bulan Januari 2017 ditemukan 24 spesies diatom epipelik. Spesies yang sering ditemukan pada penelitian ini adalah Pleurosigma clavei, Rhabdonema arcuatum, Synedra gailloni dan Gomphonema angustatum. Kelimpahan total diatom epipelik di estuari Suwung tertinggi pada bulan januari 2017 yaitu 8,82 Ind/ $\mathrm{m}^{2}$ dan kelimpahan diatom epipelik terendah yaitu 0,41 $\mathrm{Ind} / \mathrm{m}^{2}$. Penilaian pencemaran dengan menggunakan diatom epipelik menggunakan dua metode yaitu berdasarkan indeks keanekaragaman dan indeks saprobik. Penilaian pencemaran berdasarkan indeks keanekaragaman menunjukkan bahwa pada bulan Desember 2016 bervariasi yaitu belum tercemar, tercemar ringan, tercemar sedang sedangkan penilaian berdasarkan indeks saprobik bervariasi yaitu bersih, cukup tercemar dan tercemar berat. Penilaian pencemaran dengan indeks saprobik digunakan untuk mengetahui pencemaran bahan organik. Pada bulan Januari 2017 dari indeks keanekaragaman dan indeks saprobik memiliki pola yang sama yaitu sebagian besar stasiun penelitian di estuari Suwung tergolong tercemar sedang dan terdapat peningkatan pencemaran.
\end{abstract}

Kata Kunci: diatom epipelik; indeks keanekaragaman; indeks saprobik 


\section{Pendahuluan}

Kawasan estuari merupakan suatu ekosistem pesisir yang rentan terhadap kegiatan manusia dan adanya proses- proses alamiah (Zamroni dan Rohyani, 2008). Salah satu kawasan estuari yang produktif adalah kawasan estuari Suwung. Hal ini dilihat dari adanya vegetasi mangrove di sepanjang estuari Suwung. Kegiatan terbesar yang dilakukan oleh manusia pada kawasan estuari suwung adalah pemanfaatan sebagai Tempat Pembuangan Akhir (TPA) yang berlokasi dekat dengan areal mangrove. TPA Suwung terletak dikawasan Suwung Kauh dengan luas sekitar 40 Ha.

TPA Suwung berfungsi menampung sampah dari Badung, Tabanan dan Gianyar dengan menggunakan sistem open dumping (Saraswati dkk., 2017). Sistem open dumping merupakan sistem dimana sampah hanya ditimbun disuatu tempat tanpa ada perlakuan, yang akan menimbulkan dampak negatif bagi lingkungan meliputi dampak pencemaran terhadap air tanah, air sungai, dan air laut laut (Arbain, 2008). Sampah yang tertimbun di lokasi TPA akan menghasilkan cairan dengan kandungan mineral dan zat organik tinggi yang biasa dikenal dengan leachate/air lindi (Farastika, 2017). Leachate akan mengalir di permukaan tanah yang berdampak pada air permukaan, sedangkan leachate yang masuk ke dalam tanah akan mencemari air tanah dangkal di sekitarnya (Supriyadi et al, 2013). Penelitian lain yang dilakukan oleh Yatim dan Muklis (2013) menyatakan bahwa sistem open dumping di TPA Air Dingin, Kota Padang akan menghasilkan leachate yang mengalami perembesan sehingga mencemari lingkungan sekitar.

Untuk mengetahui kondisi pencemaran suatu perairan dapat digunakan dua metode yaitu metode fisika-kimia dan metode biologi (Pasisingi, 2014). Penelitian dengan menggunakan metode fisika -kimia telah dilakukan oleh Arbain (2008) di TPA Suwung untuk meneliti resapan leachate pada air tanah dangkal Hasil yang diperoleh dimana pada jarak 1 - 375 meter dari TPA Suwung sudah tergolong pada pencemaran berat. Sedangkan penelitian menggunakan metode biologi dengan indikator BOD telah dilakukan oleh Saraswati, 2017), dimana perairan estuari Suwung mengalami pencemaran ringan.

Penilaian kondisi perairan dengan metode biologi lebih unggul dibandingkan metode fisika- kimia, karena respon makhluk hidup mampu menggambarkan kondisi perubahan lingkungan secara kontiyu (Junshum et al., 2008). Penggunaan biota untuk mendeteksi kondisi suatu perairan dinamakan sebagai bioindikator. Banyak jenis biota yang dapat digunakan sebagai bioindikator, namun diatom merupakan salah satu bioindikator yang sangat potensial karena diatom merespon terhadap perubahan fisik dan kimia lingkungan (Soeprobowati, 2010).

Diatom epipelik (menempel pada sedimen) digunakan sebagai bioindikator karena kelimpahannya paling banyak di sedimen dan tersebar luas (Supono, 2008 dan Hasrun, 2013). Penelitian di Karibia melaporkan bahwa diatom pada zona pesisir ditemukan $70-90 \%$ dari keanekaragaman spesiesnya (Aké-Castillo, J.A., Vazquez, G., 2008 in Desrosiers, 2013). Diatom epipelik dapat menggambarkan perubahan kondisi lingkungan dalam jangka waktu pendek maupun panjang (Supono, 2008). Diatom epipelik dapat hidup di dearah antara eutrofik sampai hipereutrofik dimana terdapat spesies tertentu yang mendominasi (Soeprobowati, 2011). Kelebihan lainnya dari diatom epipelik yang digunakan sebagai bioindikator karena distribusinya tidak terpengaruh oleh arus (Almeida, 2001 in Supono, 2008). Berdasarkan permasalahn yang terdapat di estuari Suwung terutama yang dekat dengan TPA Suwung maka diperlukan penelitian mengenai tingkat pencemaran dengan menggunakan diatom epipelik sebagai bioindikator. Penelitian ini bertujuan untuk menentukan tingkat pencemaran di estuari Suwung dengan menggunakan diatom epipelik sebagai bioindikator.

\section{Metode Penelitian}

\subsection{Waktu dan Tempat}

Penelitian diatom epipelik sebagai bioindikator pencemaran dilakukan di estuari Suwung, Denpasar, Bali. Penelitian ini dilakukan sebanyak dua kali. Penelitian pertama dilakukan pada tanggal 13 Desember 2016. Penelitian bulan kedua dilaksanakan pada tanggal 9 Januari 2017.

\subsection{Penentuan Lokasi Sampling}

Penentuan stasiun penelitian dengan metode purposive sampling. Pada penelitian ini terdapat 9 stasiun penelitian yang disusun seperti Gambar 3. 


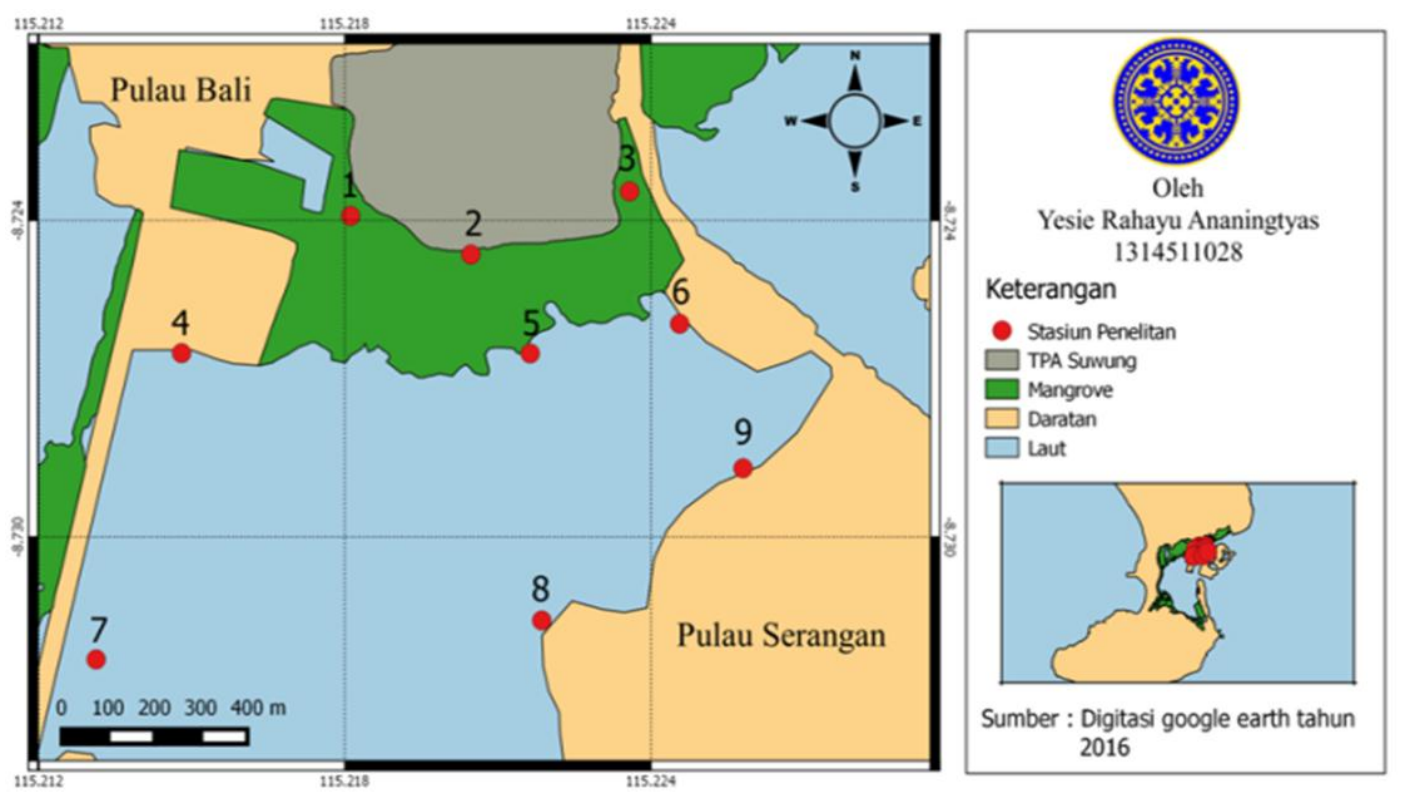

Gambar 1. Lokasi Penelitian di estuari Suwung, Denpasar, Bali

Adapun karakteristik dari stasiun penelitiian tersebut adalah :

1. Stasiun 1, 2 dan 3 merupakan daerah yang dekat dengan TPA Suwung, dimana stasiun 2 terdapat pipa pembuangan leachete dari TPA dan stasiun 3 berada di muara sungai.

2. Stasiun 4, 5 dan 6 merupakan daerah diluar area mangrove, dimana stasiun 4 merupakan daerah yang dekat dengan pipa pembuangan limbah dari restoran.

3. Stasiun 7,8 , dan 9 merupakan daerah yang jauh dari TPA Suwung, dimana stasiun 7 dekat dengan Pelabuhan Benoa dan stasiun 9 tegak lurus dengan stasiun 6.

\subsection{Metode pengambilan sampel diatom}

Pengambilan sampel diatom epipelik dilakukan ketika surut terendah (spring tide). Sampel sedimen diambil menggunakan alat pipa yang berlubang (corer) dengan diameter $10 \mathrm{~cm}$ dan tinggi $1 \mathrm{~cm}$. Kemudian sampel sedimen dibawa ke laboratorium Fakultas Kelautan dan Perikanan, Universitas Udayana.

Sampel sedimen diencerkan dengan $2 \mathrm{~mL}$ aquades dan dicampurkan agar homogen kemudian dituangkan pada cawan petri sampai ketinggian $1 \mathrm{~cm}$. Pengambilan diatom epipelik pada sedimen dilakukan dengan metode "lens tissue trapping technique". Metode "lens tissue trapping technique" mengacu pada penelitian
Supono (2008), Hendrarto (2011) dan Bate (2013) untuk mengetahui diatom epipelik. Teknik ini dapat mengcover 70\% diatom epipelik (Round, 1993). Pada lapisan permukaan sedimen diletakkan kertas saring seluas permukaan sedimen yang terdapat pada cawan petri. Sampel diletakkan diruangan terbuka dengan kondisi terkena banyak sinar matahari pada pukul 9.0010.00. Kertas saring diambil dan dimasukkan dalam botol sampel serta ditambahkan $10 \mathrm{~mL}$ formalin $4 \%$. Kemudian sampel diamati menggunakan mokroskop dengan perbesaran 100X. Diatom epipelik diidentifikasi berdasarkan Newell (1977).

\subsection{Analisa Data}

\subsubsection{Kelimpahan}

Untuk menghitung kelimpahan diatom digunakan rumus modifikasi Lackey Drop Microtransecting Methods (Hasrun, 2013) pada persamaan 1.

$\mathrm{N}=\frac{\mathrm{Oi}}{\mathrm{Op}} \times \frac{\mathrm{Vr}}{\mathrm{V}_{\mathrm{o}}} \times \frac{1}{\mathrm{~V}} \frac{\mathrm{ni}}{\mathrm{p}}$

Dimana :

$\mathrm{N}=$ jumlah diatom epipelik per satuan luas (ind $/ \mathrm{m}^{3}$ )

$\mathrm{Oi}=$ luas gelas penutup $\left(\mathrm{m}^{2}\right)$

$\mathrm{Op}=$ luas satu lapang pandang $\left(\mathrm{m}^{2}\right)$

$\mathrm{Vr}$ = volume larutan dalam botol sampel (ml) 
Vo = volume sampel yang diamati $(\mathrm{ml})$

$\mathrm{V} \quad=$ Volume pengambilan sedimen $\left(\mathrm{m}^{3}\right)$

ni = jumlah spesies diatom epipelik ke-i

$\mathrm{P} \quad$ = jumlah lapang pandang (1000)

Kelimpahan diatom epipelik diklasifikasikan berdasarkan 3 kategori menurut Hasrun (2013) yang terdapat pada Tabel 1.

Tabel 1

Frekuensi kelimpahan diatom epipelik

\begin{tabular}{ccc}
\hline Kelimpahan & Kategori & Simbol \\
\hline $\begin{array}{c}\text { Nilai kelimpahan yaitu } \\
<1 \% \text { dari kelimpahan } \\
\text { total diatom }\end{array}$ & $\begin{array}{c}\text { kelimpahan } \\
\text { diatom }\end{array}$ & $*$ \\
rendah & \\
$\begin{array}{c}\text { Nilai kelimpahan yaitu 1- } \\
\text { 3\% dari kelimpahan total } \\
\text { diatom }\end{array}$ & diatom sedang & \\
$\begin{array}{c}\text { Nilai kelimpahan yaitu } \\
>3 \% \text { dari kelimpahan } \\
\text { total diatom }\end{array}$ & kelimpahan & $* * *$ \\
& diatom tinggi & \\
\hline
\end{tabular}

\subsubsection{Keanekaragaman}

Indeks keanekaragaman diatom epipelik dihitung dengan menggunakan rumus indeks ShannonWiener Yudasmara (2015) yaitu pada persamaan 2.

$H^{\prime}=-\sum_{i=1}^{n}\left(\frac{n i}{N}\right) \operatorname{Ln}\left(\frac{n i}{N}\right)$

dimana:

$\mathrm{H}^{\prime} \quad$ : Indeks diversitas Shannon-Wiener

$\mathrm{Ni} \quad$ : Jumlah individu spesies ke-i

$\mathrm{N} \quad$ : Jumlah individu semua spesies

Kisaran total Indeks Keanekaragaman dan klasifikasi derajat pencemaran menurut Lee et.al (1978) dapat diklasifikasikan sesuai dengan Tabel 2.

\subsubsection{Indeks Saprobik}

Indeks saprobik merupakan sistem yang digunakan untuk mengetahui pencemaran perairan dengan bahan organik (Ramadhan et al., 2016). Jumlah dan frekuensi dari spesies diatom yang dianalisis untuk menghitung indeks saprobik. Rumus indeks saprobik (IS) berdasarkan Pantle and Buck (1955) pada persamaan 3.

$\mathrm{IS}=\frac{\sum(\mathrm{S} \times \mathrm{h})}{\sum \mathrm{h}}$

Dimana
IS : Indeks saprobic

s : nilai indikator dari masing-masing spesies menurut tabel Denys (1991)

h $\quad$ : frekuensi masing-masing spesies yang ditemukan

Kategori frekuensi masing-masing spesies yang ditemukan dibedakan menjadi tiga menurut Pantle and Buck (1955) yang terdapat pada Tabel 3.

\section{Tabel 2}

Klasifikasi derajat pencemaran berdasarkan indeks keanekaragaman

\begin{tabular}{cc}
\hline Indeks Keanekaragaman & Derajat Pencemaran \\
\hline$>2,0$ & Belum tercemar \\
$1,6-2,0$ & Tercemar ringan \\
$1,0-1,5$ & Tercemar sedang \\
$<1,0$ & Tercemar berat \\
\hline
\end{tabular}

Tabel 3

Kategori frekuensi masing-masing spesies

\begin{tabular}{cc}
\hline Frekuensi & Kategori \\
\hline 1 & spesies yang jarang atau kelimpahannya \\
rendah \\
3 & $\begin{array}{c}\text { spesies yang sering ditemui atau } \\
\text { kelimpahan sedang } \\
\text { spesies yang paling melimpah atau } \\
\text { kelimpahan tinggi }\end{array}$ \\
\hline
\end{tabular}

Hasil perhitungan dari Indeks Saprobik kemudian dikategori menurut Pantle and Buck (1955) yang terdapat pada Tabel 4.

Tabel 4

Kategori Indeks Saprobik

\begin{tabular}{cc}
\hline $\begin{array}{c}\text { Indeks Saprobik } \\
(\text { IS) }\end{array}$ & Kategori \\
\hline $1-1,5$ & oligosaprobity (bersih) \\
$1,5-2,5$ & beta-mesosaprobity (cukup \\
& tercemar) \\
$2,5-3,5$ & alpha-mesosaprobity (tercemar \\
& berat) \\
$3,5-4$ & polysaprobity (terlalu tercemar) \\
\hline
\end{tabular}

\section{Hasil dan Pembahasan}

\subsection{Kelimpahan Diatom Epipelik}

Pada bulan Desember 2016 spesies diatom yang ditemukan sebanyak 33 spesies (Tabel 5). Tabel 6 
Tabel 5

Spesies Diatom Epipelik yang ditemukan selama Penelitian Bulan Desember 2016 di Estuari Suwung

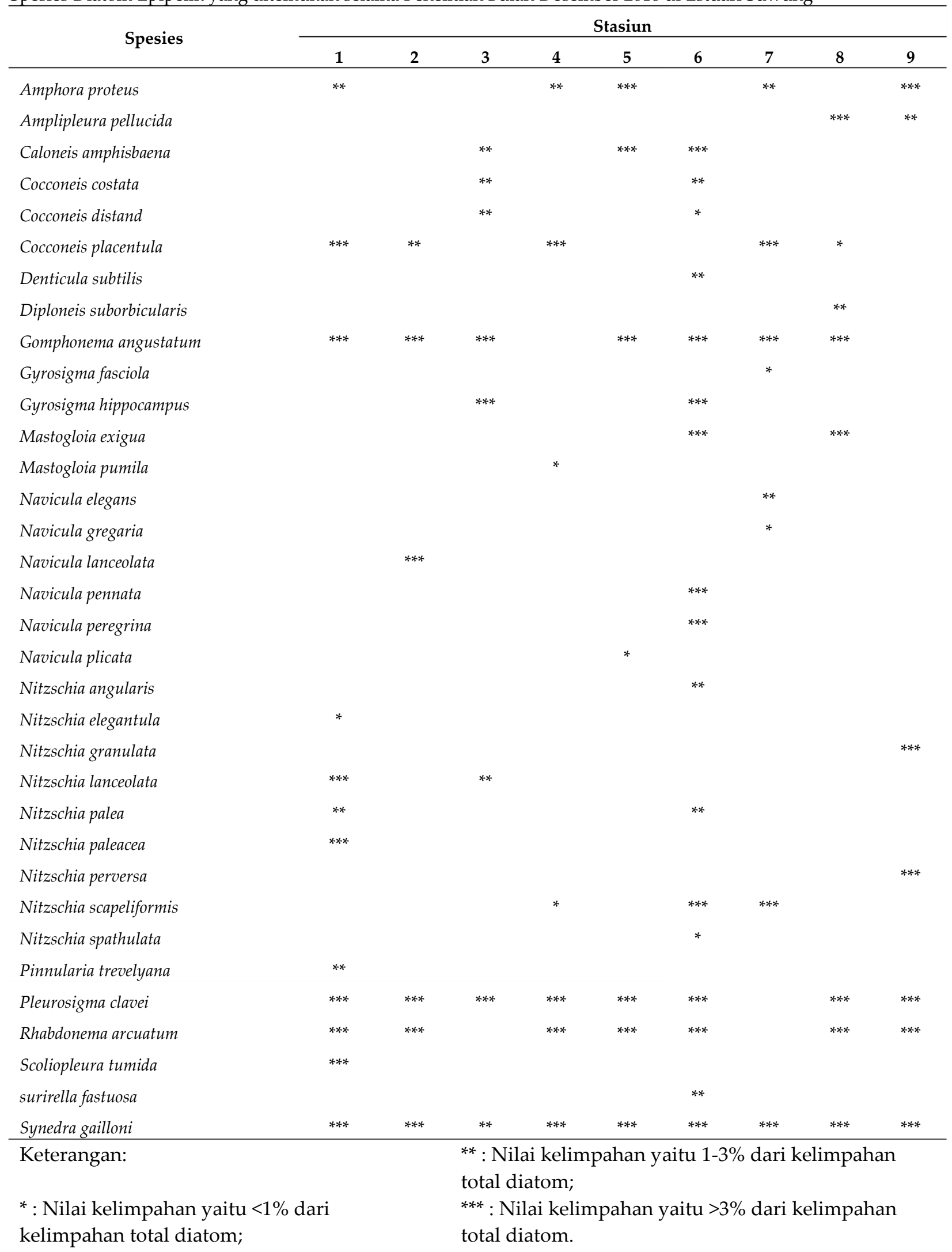

menunjukkan spesies diatom yang ditemukan pada bulan Januari 2017. Pada bulan januari 2017 ditemukan 24 spesies diatom. Spesies diatom epipelik yang ditemukan pada bulan januari 2017 lebih sedikit dibandingkan dengan bulan desember 2016. Kelimpahan total diatom epipelik 
Tabel 5

Spesies Diatom Epipelik yang ditemukan selama Penelitian Bulan Januari 2017 di Estuari Suwung

\begin{tabular}{|c|c|c|c|c|c|c|c|c|c|}
\hline \multirow{2}{*}{ Spesies } & \multicolumn{9}{|c|}{ Stasiun } \\
\hline & 1 & 2 & 3 & 4 & 5 & 6 & 7 & 8 & 9 \\
\hline Achanthes manifera & & & & & & & & $* * *$ & \\
\hline Amphora leavis & & & & & & $* *$ & & & \\
\hline Amphora proteus & & & & $* * *$ & * & & * & $* *$ & $* * *$ \\
\hline Amphora staurophora & & & & $* * *$ & & & & & \\
\hline Cocconeis placentula & & & & * & & & & & \\
\hline Cocconeis scutellum & & * & & & & & & & \\
\hline Gomphonema angustatum & & $* * *$ & $* *$ & * & $* * *$ & $* * *$ & $* *$ & * & $* * *$ \\
\hline Gomphonema arcuatum & & & & & & & & $* *$ & $* * *$ \\
\hline Gramatophora oceanica & & & & & $* * *$ & $* * *$ & & $* * *$ & \\
\hline Mastogloia exigua & & & & * & & & & & \\
\hline Mastogloia pumila & $* * *$ & & & & & & & & \\
\hline Navicula contenta & & & * & & & & & & \\
\hline Navicula elegans & & & $* * *$ & & & & & & \\
\hline Navicula lancaeolata & $* * *$ & $* * *$ & $* * *$ & $* *$ & $* *$ & & $* * *$ & & \\
\hline Navicula ramosissima & & & & & $* * *$ & & & & \\
\hline Nitzschia granulata & & & & & & & & & $* * *$ \\
\hline Nitzschia perversa & & & * & & & & & & $* * *$ \\
\hline Nitzschia scapelliformis & & & & & * & & & & \\
\hline Nitzschia supralitorea & & & & & & $*$ & & & \\
\hline Pleurosigma clavei & $* * *$ & $* * *$ & $* * *$ & $* * *$ & $* * *$ & $* * *$ & $* * *$ & $* *$ & $* *$ \\
\hline Rhabdonema acuminatum & & $* * *$ & & $* * *$ & $* * *$ & $* * *$ & $* * *$ & $* * *$ & \\
\hline Scoliopleura tumida & & & & & & & & $* *$ & *** \\
\hline Surirella fastuosa & $* * *$ & & & & & & & & \\
\hline Synedra gailloni & $* *$ & & $* * *$ & & $* * *$ & & $* * *$ & $* * *$ & \\
\hline
\end{tabular}

Keterangan Tabel 9:

* : Nilai kelimpahan yaitu $<1 \%$ dari kelimpahan total diatom;

terdapat pada Gambar 2 yang menunjukkan bahwa kelimpahan tertinggi terdapat pada stasiun 3 pada bulan Januari 2017 sedangkan kelimpahan terendah terdapat pada stasiun 8 pada bulan Desember 2016.

\subsection{Indeks Keanekaragaman}

Hasil perhitungan indeks keanekaragaman diatom epipelik pada masing-masing stasiun di bulan Desember 2016 dan Januari 2017 ditunjukkan pada Gambar 3. Nilai indeks keanekaragaman di estuari Suwung pada bulan Desember 2016 berkisar antara 1,1 - 2,4. Pada bulan Januari 2017 indeks keanekaragaman diatom epipelik berkisar antara 0,8 - 1,8. Indeks keanakaragaman dapat
** : Nilai kelimpahan yaitu 1-3\% dari kelimpahan total diatom; *** : Nilai kelimpahan yaitu $>3 \%$ dari kelimpahan total diatom.

menggambarkan kekayaan jenis diatom epipelik yang terdapat disuatu tempat (Saifullah, 2015).

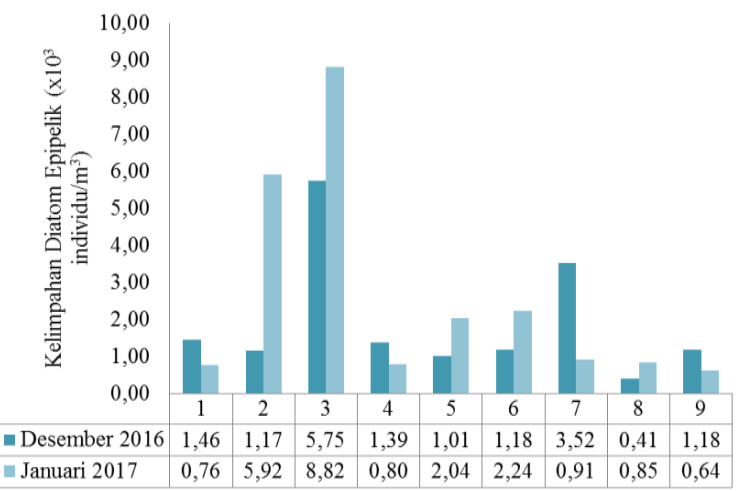

Gambar 2. Kelimpahan Total Diatom Epipelik di Estuari Suwung 


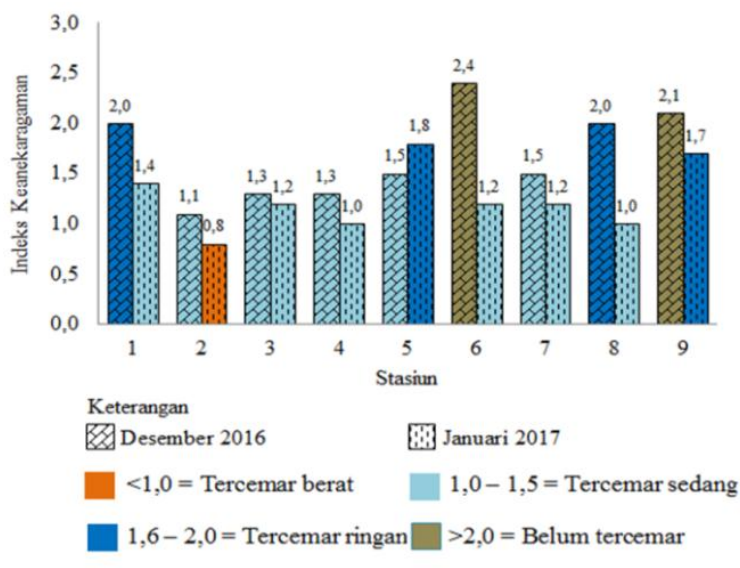

Gambar 3. Indeks Keanekaragaman Diatom Epipelik di Estuari Suwung

Pada bulan Desember 2016 sebagian besar daerah di estuari Suwung tergolong tercemar sedang yaitu terdapat pada stasiun 2, 3, 4, 5, dan 7 . Stasiun yang tergolong dalam pencemaran ringan yaitu pada stasiun 1 dan 8 sedangkan stasiun yang tergolong belum tercemar terdapat pada stasiun 6 dan 9. Penilaian pencemaran pada bulan Januari 2017 diperoleh sebagian besar daerah di estuari suwung tergolong tercemar sedang yaitu stasiun 3 , 4, 6, 7 dan 8 sedangkan pada stasiun 2 tergolong tercemar berat dan stasiun 1, 5 dan 9 tergolong tercemar ringan. Pada bulan Januari 2017 terdapat beberapa stasiun yang mengalami peningkatan kadar pencemaran yaitu pada stasiun 2, 6 dan 9 . Perbedaan penarikan kesimpulan pada indeks keanekaragaman dikarenakan jumlah spesies yang ditemukan pada masing - masing stasiun berbeda. Indeks keanekaragaman dipengaruhi oleh jumlah spesies yang terdapat pada stasiun penelitian. Hal ini sesuai dengan pendapat dari Kupe et al. (2008) yang menyatakan bahwa indeks keanekaragaman dipengaruhi oleh jumlah spesies yang ditemukan.

\subsection{Indeks Saprobik}

Hasil perhitungan tingkat pencemaran berdasarkan indeks saprobik di estuari Suwung pada bulan Desember 2016 dan Januari 2017 terdapat pada Gambar 4. Pada bulan desember 2016 terlihat bahwa kondisi pencemaran di estuari Suwung terbagi menjadi tiga golongan tingkat pencemaran. Stasiun yang termasuk dalam golongan cukup tercemar atau beta-mesosaprobity terdapat pada stasiun 1, 3, 4 dan 5. Stasiun 1 dan 3 merupakan daerah yang dekat dengan TPA Suwung tetapi pada stasiun 1 terdapat daratan di antara stasiun 1 dan 2 yang memungkinkan leachete masuk dengan konsentrasi yang rendah. Stasiun 4 merupakan daerah yang dekat dengan pipa pembuangan limbah restoran. Stasiun 5 merupakan daerah yang tegak lurus dengan stasiun 2 dengan kondisi pencemaran tercemar berat.

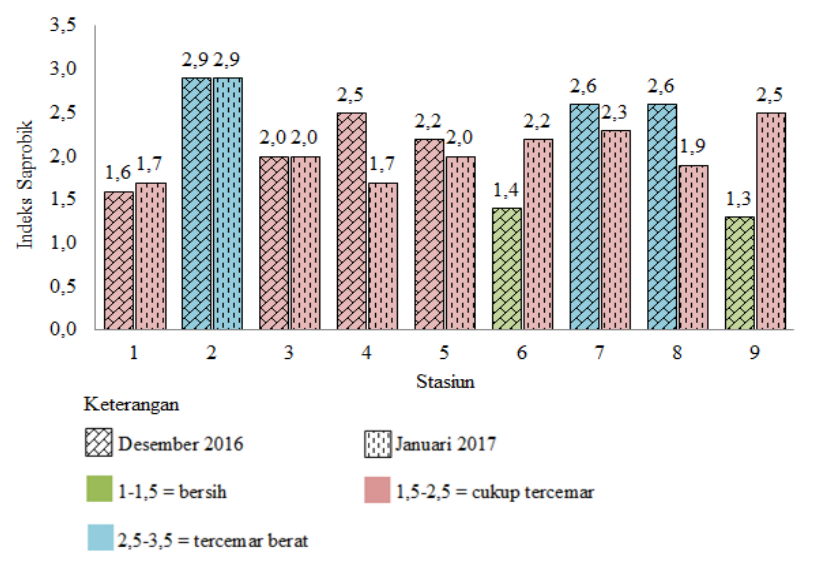

Gambar 4. Indeks Saprobik Diatom Epipelik di Estuari Suwung

Tingkat pencemaran dengan golongan tercemar berat atau alpha-mesosaprobity terdapat pada stasiun 2, 7, dan 8. Stasiun 2 merupakan daerah yang dekat dengan pipa pembuangan leachete dari TPA Suwung. Stasiun 7 merupakan daerah yang dekat dengan pelabuhan Benoa. Stasiun 8 merupakan daerah yang tegak lurus dengan stasiun 2 dan 5, yang memungkinkan leachate mengarah ke stasiun 8 namun dengan konsentrasi yang berbeda. Pada stasiun 6 dan 9 termasuk dalam golongan bersih atau oligosaprobity. Hal ini diduga karena limbah dari stasiun 3 tidak mengarah ke stasiun 6 dan 9 . Limbah dari stasiun 3 diduga mengarah ke stasiun 7 dan 8 karena adanya arus yang berasal dari stasiun 6 dan 9 ke pelabuhan benoa. Menurut Yastika dkk. (2012) dan Rachman dkk. (2016) menyatakan bahwa pergerakan arus dari pasang menuju surut adalah mengarah ke pelabuhan Benoa. Karena pergerakan arus tersebut akan berpengaruh terhadap persebaran limbah (Indrayana et al., 2014). Pada bulan Januari 2017 di dapatkan hasil bahwa sebagian besar stasiun penelitian tergolong cukup tercemar atau betamesosaprobity. Dibandingkan bulan Desember 2016 tingkat pencemaran di stasiun 7 dan 8 pada bulan Januari 2017 mengalami penurunan tingkat pencemaran. pada stasiun 6 dan 9 mengalami 
peningkatan pencemaran, sedangkan pada stasiun 2 tingkat pencemarannya sama.

Penilaian pencemaran dengan indeks saprobik digunakan untuk mengetahui pencemaran bahan organik. Pada stasiun 1, 2 dan 3 merupakan daerah yanng dekat dengan TPA Suwung, dimana pada stasiun 2 mengalami pencemaran berat dikarena lokasi penelitian yang dekat dengan sumber limbah, dimana sampah yang terdapat di TPA Suwung merupakan sampah domestik yang menghasilkan limbah dengan kandungan bahan organik yang tinggi. Menurut Arbain (2008) menjelaskan bahwa air limbah yang berasal dari TPA Suwung banyak mengandung bahan organik yang tinggi. Menurut Yatim dan Muklis (2013) menjelaskan bahwa sampah domestik yang ditimbun akan menghasilkan leachate dengan kandungan bahan organik tinggi. Semakin dekat dengan sumber limbah maka tingkat pencemarannya akan semakin tinggi. Penelitian yang dilakukan oleh Hassan dan Shawiat (2016) menyatakan bahwa daerah yang dekat dengan kebocoran limbah domestik mengandung bahan organik tinggi.

\section{Simpulan}

Penelitian pencemaran di estuari Suwung dengan bioindikator diatom epipelik didasarkan atas dua indeks yaitu indeks keanekaragaman dan indeks saprobik. Berdasarkan indeks keankekaragaman menunjukkan bahwa pada bulan Desember 2016 terdapat 2 stasiun tergolong tercemar ringan, 5 stasiun tergolong tercemar sedang dan dua stasiun tergolong bersih. Dibandingkan dengan bulan Desember 2016, pada bulan Januari 2017 terdapat 4 stasiun mengalami peningkatan pencemaran, 2 stasiun mengalami penurunan dan 3 stasiun hasilnya sama selama dua kali penelitian. Berdasarkan indeks saprobik menunjukkan bahwa pada bulan Desember 2016 terdapat 4 stasiun tegolong cukup tercemar, 3 stasiun tergolong tercemar berat dan 2 stasiun tergolong bersih. Pada bulan Januari 2017 terdapat 2 stasiun mengalami peningkatan pencemaran, 2 stasiun mengalami penurunan tingkat pencemaran dan 5 stasiun tingkat pencemarannya selama dua kali penelitian sama.

\section{Ucapan Terima Kasih}

Penulis mengucapkan terima kasih kepada UPT Pengelolaan Sampah TPA SARBAGITA yang telah memberikan izin memasuki ke area TPA Suwung. Penulis mengucapkan terima kasih kepada orang tua yang telah mendoakan dan memberikan dana untuk penelitian ini. Penulis juga berterima kasih kepada Luh Pt Priyandayani, Yuli Krisnawati, Ni Luh Novita Arianti, Jajang Nuryana, Hassanudin Sondang Dongoran, Parulian Sihombing, Eriq Imanuel, dan Wahyu Ilvita Vindya yang telah membantu dalam pengambilan sampel di lapangan.

\section{Daftar Pustaka}

Arbain, Mardana, N. K., \& Sudana, I. B. (2008). Pengaruh Air Lindi Tempat Pembuangan Akhir Sampah Suwung terhadap Kualitas Air Tanah Dangkal di Sekitarnya di Kelurahan Pedungan Kota Denpasar. Ecotrophic: Journal of Environmental Science, 3(2), 55-60.

Bate, G. C. (2013). Epipelic diatoms in the estuaries of South Africa. Water SA, 39(1), 105-118.

Denys, L. (1991). A check-list oj the diatoms in the holocene deposits of the Western Belgian coastal plain with a survay oj their apparent ecological requirements, I. Introduction, ecological code and complete list. Berchem, Belgium: Belgische Geologische Dienst, Professional Paper 1991192-N 246.

Desrosiers, C., Leflaive, J., Eulin, A., \& Ten-Hage, L. (2013). Bioindicators in marine waters: benthic diatoms as a tool to assess water quality from eutrophic to oligotrophic coastal ecosystems. Ecological indicators, 32, 25-34.

Farastika, D. (2017). Pengaruh resirkulasi lindi secara anaerobik pada sampah segar dan sampah tpa batu layang, pontianak. Jurnal Mahasiswa Teknik Lingkungan UNTAN, 1(1), 1-10.

Hasrun, L. O., Kasim, M., \& Salwiyah, S. (2013). Studi biodiversitas diatom bentik pada areal mangrove di perairan kecamatan Kolono kabupaten Konawe selatan . Jurnal Mina Laut Indonesia, 2(6) : 35-47.

Hassan, F. M., \& Shawiat, A. O. (2016). Assessment of a lotic ecosystem by using diatomic indices (epipelic algae), Iraq. Mesopotamia Environmental Journal, 2(2), 87-100.

Hendrarto, I. B., \& Nitisuparjo, M. (2011). Biodiversity of benthic diatom and primary productivity of benthic micro-flora in mangrove forests on central Java. Journal of Coastal Development, 14(2), 131-140.

Indrayana, R., Yusuf, M., \& Rifai, A. (2014). Pengaruh Arus Permukaan Terhadap Sebaran Kualitas Air Di Perairan Genuk Semarang. Jurnal Oseanografi, 3(4), 651-659.

Junshum, P., Choonluchanon, S., \& Traichaiyaporn, S., (2008). Biological indices for classification of water quality around Mae Moh power plant, Thailand. 
Maejo International Journal of Science and Technology, 2(01), 24-36.

Kupe, L., Schanz, F., \& Bachofen, R. (2008). Biodiversity in the benthic diatom community in the upper River Töss reflected in water quality indices. Clean-Soil, Air, Water, 36(1), 84-91.

Lee, C. D., Wang, S. B., \& Kuo, C. L. (1978). Benthic Macroinvertebrate and Fish as Biological Indicators of Water Quality, with Reference to Community Diversity Index. Bangkok, Thailand: International Conference on Water Pollution Control in Development Countries.

Newell, G. E., \& Newell, R. C. (1977). Marine Plankton, a Practical Guide. (5 ${ }^{\text {th }}$ Ed.). London, UK: Hutchinson \& Co (Publishers) Ltd.

Pantle, R., \& Buck, H. (1955). Die biologisch Uberwachung der Gewasser und die Darstellung der Ergebnisse. Gas und Wasserfach, 96: 604-607

Pasisingi, N. (2014). Diatom Epilitik sebagai Indikator Kualitas Air di Bagian Hulu Sungai Cileungsi, Bogor. Tesis. Bogor, Indonesia: Program Studi Pengelolaan Sumberdaya Perairan, Program Pascasarjana Institut Pertanian Bogor.

Rachman, H. A., Hendrawan, I. G., \& Putra, I. D. N. N. (2016). Studi Transpor Sedimen Di Teluk Benoa Menggunakan Pemodelan Numerik. Jurnal Kelautan: Indonesian Journal of Marine Science and Technology, 9(2), 144-154.

Ramadhan, F., Rijaluddin, A. F., \& Assuyuti, M. (2016). Studi indeks saprobik dan komposisi fitoplankton pada musim hujan di situ gunung, sukabumi, jawa barat. Al-Kauniyah: Jurnal Biologi, 9(2), 95-102.

Raund, F. E. (1993). A Reviev and Methods for The Use of Epilithic Diatoms for Detecting and Monitorin Changes in River Water Quality: Methods for the Examination of Waters and Associated Materials. London, UK: HMSO Books.
Saifullah, S. (2015). Water Quality of Situ Cibanten Based on Shannon-Weaver Diversity Index Value. Jurnal Perikanan dan Kelautan, 5(1), 1-4.

Saraswati, N. L. G. R. A., Arthana, I. W., \& Hendrawanb, I. G. (2017). Analisis Kualitas Perairan Pada Wilayah Perairan Pulau Serangan Bagian Utara Berdasarkan Baku Mutu Air Laut. Journal of Marine and Aquatic Sciences, 3(2), 163-170.

Soeprobowati, T. R. R., \& Suedy, S. W. (2010). Komunitas diatom pada ekosistem mangrove pantai utara jawa tengah. Jurnal Sains Dan Matematika, 18(3), 94-102..

Soeprobowati, T. R., Hidayat, J. W., \& Baskoro, K. (2011). Diatom Epipelik sebagai Bioindikator Kualitas Perairan Danau Rawa Pening. Jurnal Sains Dan Matematika, 19(4), 107-118.

Supono. (2008). Analisis indeks true diversitas diatom eipelic tambak udang dengan tekstur tanah yang berbeda. Maspari Journal, 8(1): 31-38.

Supriyadi, S., Khumaedi, K., \& Panca, R. N. (2013). Pola sebaran limbah tpa studi kasus di Jatibarag Semarang. Jurnal Manusia dan Lingkungan, 20(1), 4956.

Yastika, P. E. Suyanto, H., \& Hendrawan, I. G. (2012). Pemodelan numerik pola arus pasang surut di Teluk Benoa, Bali. Buletin Fisiska, 13(2) :60-66.

Yatim, E. M., \& Mukhlis, M. (2013). Pengaruh Lindi (Leachate) Sampah Terhadap Air Sumur Penduduk Sekitar Tempat Pembuangan Akhir (TPA) Air Dingin. Jurnal Kesehatan Masyarakat Andalas, 7(2), 54-59.

Yudasmara, G. A. (2015). Analisis keanekaragaman dan kemelimpahan relatif algae mikroskopis di berbagai ekosistem pada kawasan intertidal pulau menjangan bali barat. Jurnal Sains Dan Teknologi, 4(1), 503-515.

Zamroni, Y., \& Rohyani, I. S. (2008). Produksi serasah hutan mangrove di perairan pantai Teluk Sepi, Lombok Barat. Jurnal Biodiversitas, 9(4), 284-287.

(C) 2017 by the authors; licensee Udayana University, Indonesia. This article is an open access article distributed under the terms and conditions of the Creative Commons Attribution license (http://creativecommons.org/licenses/by/3.0/). 